\title{
Huffmanela spp. (Nematoda: Trichosomoididae) from Orange-spotted Grouper (Epinephelus coioides, Hamilton, 1822) at Jubail Province, on the Arabian Gulf, Saudi Arabia: A case report
}

marwa Attia ( $\square$ marwaattia.vetpara@yahoo.com )

Cairo University Faculty of Veterinary Medicine

Mahmoud A. Mahmoud

Cairo University Faculty of Veterinary Medicine

Mustafa M. Ibrahim

Animal Health Research Institute

\section{Research Article}

Keywords: Huffmanela spp., Epinephelus coioides, granulomatous myositis

Posted Date: February 24th, 2021

DOI: https://doi.org/10.21203/rs.3.rs-223935/v1

License: (c) (1) This work is licensed under a Creative Commons Attribution 4.0 International License.

Read Full License

Version of Record: A version of this preprint was published at Journal of Parasitic Diseases on April 22nd, 2021. See the published version at https://doi.org/10.1007/s12639-021-01394-x. 


\section{Abstract}

This paper is conducted for identifying the parasite which collected during regular routine inspection for the hygienic condition and health status of fish in 2019 at the central fish market shops at Jubail city, Saudi Arabia. Samples from an orange spotted grouper (Epinephelus coioides) fish showed heavy black streaks between the muscle fibers that was considered unmarketable and rejected by the consumer after had been cut and prepared for sealing. The black discolorations were in the form of heavy diffused focal black spots or forming threads of variable sizes embedded in the entire whole-body musculature of the fish. These samples were subjected to parasitological and pathological evaluation. The parasitological examination of the affected muscular tissues revealed Huffmanela spp. eggs infection. The parasitic infestation was identified on the bases of the morphological and ultra-structural characters of the eggs. The histopatholgical investigation of the dark discoloration of the muscular tissues showed severe diffused multifocal granulomatous myositis reactions in the form of chronic inflammatory response accompanied with fibrous connective tissue proliferation around the eggs and larvae together with lymphocytes and macrophages aggregation. Muscular necrosis, edema and evidence of muscular regeneration were also noticed. In conclusion; this case report confirmed the occurrence of Huffmanela spp. infection in the muscles of Epinephelus coioides by using light and scanning electron microscopy.

Further molecular assessment is recommended.

\section{Introduction}

Epinephelus coioides (Hamour) was considered as the most preferred fish species consumed in the fish markets by $60-72 \%$ of Saudis (Burger et al., 2014). Huffmanela spp. (Nematoda: Trichosomoididae, Huffmanelinae) is one of the histozoic nematode parasite infecting marine fishes and less frequently freshwater fishes (Moravec et al., 1998). Furthermore, they are categorized mainly based only on the morphological feature of their eggs, and life-cycle characters such as host family and targeted tissue (Bullard et al., 2012; Ruiz et al., 2013; Justine and Iwaki, 2014).

Previous studies have shown that Huffmanela infection is one of the most common parasitic infections that adversely affect the health of various fish families, worldwide (Moravec \& Garibaldi, 2000; Moravec \& Garibaldi, 2003; Moravec et al., 2005; Esteves et al., 2009; Moravec \& Justine, 2010; Ruiz et al., 2013; AlHasson et al., 2019 and Eissa et al., 2020). The site of the lesion preference was species dependent, as previously reported for $\mathrm{H}$. lusitana infecting the muscles of pouting Trisopterus luscus (Ramos et al., 2019), while H. paronai was observed in the skin of Xiphias gladius (Justine, 2004). Also, two species of Huffmanelae were recorded in Japan ( $H$. japonica and $H$. shikokuensis) and the eggs of these parasites were found in the flesh of Upeneus bensasi and Stephanolepis cirrhifer (Moravec et al., 1998). Moreover, Moravec and Campbell, 1991, further recorded the presence of $H$. schouteni in serosa covering intestine; abdominal cavity and liver from flying fishes Hirundichthys affinis and Cypselurus cyanopterus. 
The aim of the current study was to identify the causative agent of black muscular tissue discoloration and describing the associated pathological lesions in this fish species.

\section{Materials And Methods \\ 2.1. Study area}

The fishes; orange spotted grouper (Epinephelus coioides); were caught and examined from water of the Arabian Gulf at the eastern region of the Arabian Gulf; at fish landing stations, market shops and fish auctions at Jubail city ('27 $57.9^{\circ} \mathrm{N}$ and '49 $49^{\circ}$ ' 43.4" E), Saudi Arabia.

\subsubsection{Fish sample}

From January 2017 to December 2019, during the routine examination of 850 (280 female and 570 male) orange spotted grouper (Epinephelus coioides); the examined fish were ranged from $45 \mathrm{~cm}-50 \mathrm{~cm}$ with average body weight from $2,500 \mathrm{~kg}$ to $2,750 \mathrm{~kg}$.; only one male fish of orange spotted grouper (Epinephelus coioides) showed intermuscular black discoloration spots like threads. The fresh muscle specimens as well as its internal organs were examined directly under the microscope and different samples were fixed and taken for further parasitological, histopathological and ultrastructural studies.

\subsection{Parasitological examination}

Different parts of fixed muscle in $10 \%$ neutral buffered formalin had multiple black strikes (the black coloration of grade 2) were admitted to the Parasitology Department; Faculty of Veterinary Medicine; Cairo University. These lesions were examined under dissecting Stereoscope and light microscope; further, the scraped eggs from muscles were cleared in lactophenol for one hour, and then mounted in glycerol jelly (Ruiz et al., 2013). The measurements of eggs $(n=20)$ were photographed and measured using an Olympus AX70 connected to a Nikon camera. Measurements of the examined eggs (per microscopic field) were recorded in micrometers $(\mu \mathrm{m})$ with mean (minimum - maximum \pm standard deviation).

\subsection{Ultrastructure studies of eggs using Scanning electron microscope (SEM)}

The recovered eggs were prepared by fixation in $2.5 \%$ glutaraldehyde at $4^{\circ} \mathrm{C}$ for $24 \mathrm{~h}$. Further, the isolated eggs were dehydrated through passing in a grade series of ethanol; each/ 20 min., dehydrated on filter paper Whitman no.1. Then, whole dryness was occurred by $\mathrm{CO} 2$ critical point drier (Autosamdri-815, Germany). Finally, the samples were stuck on the stubs, covered with $20 \mathrm{~nm}$ gold in a sputter coater (SpiModule sputter Coater, UK). All the specimens examined and photographed by JSM 5200, Electron probe Microanalyzer, Jeol, Japan at the Faculty of Agriculture, Cairo University, Egypt; number of examined eggs were 10 which photographed by electron microscope (Ruiz et al., 2013).

\subsection{Determination of eggs morphology and measurements}


The morphological identification of the collected eggs was carried out according to the described keys and available literature (Moravec and Campbell, 1991; Ruiz et al., 2013; Justine and Iwaki, 2014). The measurements of the different stages of eggs were taken as the length; width of eggs; the length of polar plug; the thickness of the two covering layers of eggs and the thickness of its convoluted larva.

\subsection{Histopathogical examination}

Tissue specimens from infected muscles were fixed in $10 \%$ neutral buffered formalin, washed in tap water, dehydrated in ascending concentrations of ethanol, cleared in xylene and embedded in paraffin then sectioned at $5 \mu$ thicknesses. Hematoxylin and eosin (H\&E) stain was performed. All tissue processing procedures were performed according to Heil, 2009.

\section{Results}

\subsection{Parasitological results: 3.1.1. Taxonomy}

Type host: Orange spotted grouper (Epinephelus coioides, Hamilton, 1822); Saudis name "Hamour".

Site of infection: Intermuscular black spots and/or worm- like threads as a result of presence of the eggs in the musculature.

Type locality: Jubail city on the Persian Gulf coast; Saudi Arabia.

\subsubsection{Light and scanning electron microscopy of Huffmanela spp. eggs}

All the examined eggs with different stages revealed infection of orange spotted grouper muscles with Huffmanela spp. By inspection of muscle 2 stages of eggs were recorded (stage 1: light brown advanced eggs with larva; stage 2: dark brown advanced eggs with developed larva). All the examined eggs were found to be in advanced stage which had larvae.

Stage 1 (fertilized eggs; $\mathrm{n}=10$ ): advanced eggs light brown in color; the eggs was oval to spindle shaped eggs $67.46(60.3-75.6 \pm 5.2 \mu \mathrm{m})$ in length and the eggs less broad with its width ranged from 30.2 (26.4$36.5 \mu \mathrm{m} \pm 3.5)$. The protruding polar plug ranged from $8.5(6.5-10.3 \pm 1.3 \mu \mathrm{m})$; the eggs surrounded with smooth egg envelop and had two layers. The outer brown and inner clear translucent layer with eggshell thickness ranged from $4.3(3.4-5 \pm 0.7 \mu \mathrm{m})$. The eggs shell had protuberance. The eggs contained convoluted larva from 3-5 coiled within the eggs the larval thickness was $5.4(4-6.6 \pm 0.8 \mu \mathrm{m})$; Fig. $1 \mathrm{~A}$; Fig. 2A; Fig. 3A-D.

Stage 2 (fertilized eggs contain larva; $\mathrm{n}=10$ ): more advanced eggs amber brown to dark brown in color; the eggs resembles the eggs in stage 1 but differ in measurements as; the eggs were oval to spindle 
shaped with $68.3(62.5-75.3 \mu \mathrm{m} \pm 4.9)$ in length and less broad with its width ranged from 33.2 (30-36.5 $\mu \mathrm{m} \pm 2.4)$. The polar plug ranged from $6.8(6.3-9.2 \mu \mathrm{m} \pm 1)$; the eggs surround with smooth egg envelop; Fig. 1B; Fig. 3A and had two layers outer brown and inner clear and translucent layer with eggshell thickness ranged from $4.2(3-5.4 \mu \mathrm{m} \pm 0.6)$; Fig. 2B. The eggshell had protuberance which as stage 1 ; Fig. 3B-C. The eggs contain convoluted larva from $3-4$ coiled, the larval thickness $5.6(4.5-6 \pm 0.4)$ in diameter; Fig. 1C.

\subsection{Pathological results: 3.2.1. Gross lesions}

The examination of the affected fish showed multifocal black parasitic materials between the muscle fibers. Such materials were greyish white to black and appeared as thread-like and/or spots. The parasitic materials were distributed all over the fish flesh either superficially in subcutaneous area or deep inside the muscular tissue and they have been concentrated in the flesh around the vertebral column. The examined fish and affected muscles were presented in (Fig. 4A\&B). The lesion sometimes appeared as a spotted circumscribed focal lesion especially near the myosepta but in other parts of the muscles, the parasitic materials were aggregated in the form of black thread- like clusters separating the myofibers and surrounded with a delicate layer of fibrous tissue.

\subsubsection{Histopathogical findings}

The examined fresh tissue specimens using the light microscope showed multiple rounded to oval black eggs together with larvae deeply embedded in the muscle fibers. Dilated lymph vessels and fibrous connective tissue proliferation were noticed around the parasites [Fig. 4C]. Lymphatic dilation, edema and mononuclear inflammatory cells infiltration were common finding in these areas (Fig. 4D). The eggs in some of the examined sections were surrounded by shell- like structure and showing fibrous connective tissue capsule around the eggs; while the nearby muscles of the host showed myodegeneration (Fig. 4E). In other parts of the affected muscles, the eggs were deeply embedded in the myofibers and surrounded with fibrous connective tissue while the affected myofibers appeared atrophied (Fig. 4F).

The granulomatous reaction appeared either as early granuloma where many of parasitic eggs and larvae were surrounded with inflammatory cells, edema and thin layer of fibrous connective tissue (Fig. 5A) or appeared as old granuloma with thick layer of lamellate fibrous connective tissue (Fig. 5B). Cells of chronic inflammation mainly macrophages and fibroblasts with prominent muscular necrosis and myophagia were also noticed (Fig. 5C). The granulomatous reaction in other parts was characteristic and showing central area containing remnants of the black parasitic depresses surrounded with mature fibrous connective tissue layer with regenerated muscular tissue (Fig. 5D). The regenerated myofibrils appeared more easinophilic, rosette shape in cross section and with multiple centrally located nuclei (Fig. 5E) while the necrotic muscles were surrounded with melanophores (Fig. 5F).

\section{Discussion}


Based on the previous published data; there are about 21 species of Huffmanella spp. were recorded worldwide till now; these species were identified on the basis of various morphological criteria as the eggs morphology (egg length and width; shape of shell smooth or spiny either contain ridges or filaments; with envelop or not; the envelop character, which is spinose or aspinose) according to (Moravec and Fajer-Avila, 2000). Additionally, the identification was declared by the habitat of eggs either skin; gills; muscles; swim bladder; within bones; serosa of intestine and liver. Also, identification was carried out by specific host species

Accordingly; this study was applied on Orange spotted grouper (Epinephelus coioides, Hamilton, 1822) which was severely rejected in fish market due to sever black discoloration of muscles. By parasitological examination of this rejected fish; the examination revealed the presence of Huffmanela spp eggs. The Huffmanela spp was identified according to the morphological keys recorded by $\mathrm{H}$. hamo by Justine and Iwaki, 2014); H. banningi(Moravec, 1987); H. japonica (Moravec et al., 1998); H. lusitana (Ramos et al. 2019) and H. shikokuensis (Moravec et al., 1998)..

Our study revealed infection of muscles of Orange spotted grouper with Huffmanela spp. This identification was confirmed by the length and width of the eggs as $60-75 \times 26-36 \mu \mathrm{m}$ which nearly resembles to previous study with Moravec et al., 1998 whose recorded Huffmanela spp. egg length as 58-69 $\times 26-30 \mu \mathrm{m}$. Egg shell in our study had protuberance as recorded by Moravec et al., 1998. Also; in our study, the eggshell envelop was smooth which revealed by scanning electron microscope; this finding confirmed by Moravec et al., 1998.

Unfortunately; till now; there are no published molecular data on this tissue parasite for species confirmation. So; the study was confirmed by several points as egg length; width; shell envelop; either these eggs have spine; protuberance; filament or smooth eggshell.

Our study differentiated from other results in $\mathrm{H}$. huffmani which have spine on eggshell; these spines appear triangular as recorded in ultrastructure of transmission electron microscope by Žd'árská et al., 2001; indicating that it is not $\mathrm{H}$. huffmani. In this study the protuberance appeared not regular as in $\mathrm{H}$. huffmani which appeared regular in shape and distribution. Huffmanela huffmani recorded in swimbladder of freshwater fishes; Huffman and Moravec, 1988, while our study recorded in muscles of marine fishes [Orange spotted grouper].

In the previous study on $H$. japonica by Moravec et al., 1998, accumulation of eggs in groups, in muscles of the infected goatfish, Upeneus bensasi (Mullidae : Perciformes) were recorded. They found two stages of eggs (less advanced and advanced eggs) as our study; in our study this is the first time to describe these eggs with scanning electron microscope which not appeared on the previous results by Moravec et al., 1998.

There are 5 species of Huffmanela recorded to infect the muscles of marine water fishes $\mathrm{H}$. hamo (Justine and Iwaki, 2014); H. banningi(Moravec, 1987); H. japonica (Moravec et al., 1998); H. lusitana (Ramos et al. 2019) and H. shikokuensis (Moravec et al., 1998). The difference of these species 
according to the length of the eggs; eggshell and it's enveloped if present. The longest eggs of these species were $H$. banningi (99-108 x 42-45) with its shell spinose with minute canal on the envelop; and $H$. hamo; $H$. lusitana and $H$. shikokuensis were smooth shell with smooth envelop; while $H$. hamo and $H$. lusitana were smooth shell with no envelop.

In gross pathological examination, multifocal black parasitic remnants were noticed in the muscular tissue of the infected fish. This black discoloration is characteristic for Huffmanela in many fish species (Esteves et al., 2009 and Esteves et al., 2016). In histopathological examination, dilation of lymphatics may be attributed to the inflammatory reaction evoked by the host tissue against the eggs and/or larvae of the parasite. The chronic inflammatory response that appeared in the form of granulomatous myositis could be agreeable with the findings of Ramos et al., 2019 who recorded granulomatous reaction in pouting, Trisopterus luscus infected with Huffmanelaspp.. In our study, regeneration of the necrotic muscular tissue was of common occurrence In teleosts, the regeneration ability of their muscles has been confirmed by many authors (Rowlerson et al., 1997; Hans, 2012 and Saera-Vila et al., 2018).

\section{Conclusion}

From this study we could conclude that, the Huffmanela spp is reported in orange spotted grouper (Epinephelus coioides) in Saudi Arabia.

In our study, although the Huffmanela spp was recorded in only one reported case in orange spotted grouper, the severity of infection in the muscle caught our attention for the possibility Epinephelus coioides role in dissemination of this parasite to other fish species including groupers' predators in marine ecosystem as sharks.

\section{Declarations}

\section{Conflict of Interests:}

The authors declare that they have no conflict of interests.

\section{Funding:}

This research did not receive any specific grant from funding agencies in the public, commercial, or notfor-profit sectors.

\section{Data availability statement:}

The authors confirm that all the data supporting the findings of this study are available within the article.

Data availability: All the authors declare that; all the data supporting the results reported in our article were found included in this article only. 
Conflict of interest: All authors declare that they have no conflict of interest.

\section{Funding of the manuscript: No funding supporting this work.}

\section{Ethical consideration}

All authors declare that the finding in this study was conducted on fish in markets. This article does not contain any studies with animals performed by any of the authors.

\section{Author's Contributions:}

This study was conducted in cooperation between all authors. Mohamed A., Marwa M. Attia, Conceived and designed the study. Mustafa M. Ibrahim performed fish sampling and fish examination. Marwa M. Attia, examined and identified the eggs of the nematoda and photographed it; Mahmoud A. M., examined the histopathological samples and analyzed it. Mohamed A., Marwa M. Attia. wrote the manuscript; all authors; drafting, revising and approved the final manuscript.

\section{References}

Al-Hasson HAH, Al-Niaeem KS \& Al-Azizz SA (2019). Occurrence of Six Larval Nematode Species from Marine Fishes of Iraq. Biol. Appl. Environ. Res. 3 (2): 127-141.

Bullard SA, Ruiz CF, McElwain A, Murray MJ, Borucinska JD and Benz GW (2012). Huffmanela cf. carcharhini (Nematoda, Trichosomoididae, Huffmanelinae) from skin of a sandbar shark, Carcharhinus plumbeus, in the Pacific Ocean. Journal of Parasitology $98,333-340$.

Burger J, Gochfeld M, Batang Z, Alikunhi N, Al-Jahdali R, Al-Jebreen D, Aziz MAM and Al-Suwailem A (2014). Fish consumption behavior and rates in native and non-native people in Saudi Arabia. Environmental Research133, 141-148.

Carballo MC, and Navone GT (2007). A new Huffmanela species (Nematoda: Trichosomoididae) parasitizing atherinid fishes in North Patagonian Gulf, Argentina. Journal of Parasitology93, 377-382.

Eissa, I.A.M., Gadallah, A.O., Hashim, M. et al. (2020). First record of the nematode, Huffmanela sp. infecting the broomtail wrasse (Cheilinus lunulatus) from Egypt.

J Parasit Dis. https://doi.org/10.1007/s12639-020-01295-5

Esteves A, Seixas F, Carvalho S, Nazário N, Mendes M and Martins C (2009). NOTE, Huffmanela sp. (Nematoda: Trichosomoididae) muscular parasite from Trisopterus luscus captured off the Portuguese coast. Diseases of Aquatic Organisms 84, 251-255. 
Esteves A, Oliveira I, Ramos P, Carvalho A, Nazario N, Seixas F (2016). Huffmanela spp. (Nematoda, Trichosomoididae) from Microchirus azevia: Tissue Location and Correspondence of Host Muscle Discoloration with Parasite Burden. Journal of Fisheries and Aquatic Science11 (4), 304-310.

Hans GS (2012). Salamanders and fish can regenerate lost structures - why can't we? BMC Biology10, 15.

Heil N (ED) (2009). National Wild Fish Health Survey- Laboratory Procedures Manual, 5.0 Edition. U.S. Fish and Wildlife Service. Warm Springs. GA.

Huffman DG and Moravec F (1988). First description of adult Huffmanela huffmani Moravec, 1987 (nematode: Trichosomoididae) from the swimbladder of centrarchid fishes of the upper San Marcos River, Central Texas. Folia Parasitologica35, 227-234.

Justine JL (2004). Three new species of Huffmanela Moravec, 1987 [Nematoda: Trichosomoididae] from the gills of marine fish off New Caledonia. Systematic Parasitology 59, 29-37.

Justine JL (2005). Huffmanela lata n. sp. [Nematoda: Trichosomoididae: Huffmanelinae] from the shark Carcharhinus amblyrhynchos [Elasmobranchii: Carcharhinidae] off New Caledonia. Systematic Parasitology61, 181-184.

Justine JL, (2007). Huffmanela spp. [Nematoda, Trichosomoididae] parasites in coral reef fishes off New Caledonia, with descriptions of $H$. balista n. sp. and H. longa n. sp. Zootaxa1628, 23-41.

Justine JL, (2011). Huffmanela plectropomi n. sp. [Nematoda: Trichosomoididae: Huffmanelinae] from the coral grouper Plectropomus leopardus [Lacépède] off New Caledonia. Systematic Parasitology79, $139-143$.

Justine JL, Iwaki T (2014). Huffmanela hamo sp. n. [Nematoda: Trichosomoididae: Huffmanelinae] from the dagger-tooth pike conger Muraenesox cinereus off Japan. Folia Parasitologia61, 267-271.

Moravec F, (1987). Revision of Capillarità nematodes (subfamily Capillariinae) parasitic in fishes. Studie ČSAV No. 3. Academia, Praha, Českě Budějovice, Czech Republic, 141.

Moravec F, and Campbell BG (1991). A new Huffmanela species, H. schouteni sp. n. (Nematoda, Trichosomoididae), from flying fishes in Curaçao. Folia Parasitologia38, 29-32.

Moravec F, and Garibaldi F (2000). Huffmanela paronai sp. n. (Nematoda: Trichosomoididae), a new parasite from the skin of swordfish Xiphias gladius in the Ligurian Sea (Western Mediterranean) Folia Parasitologica47, 309-313.

Moravec F and Fajer-avila E (2000). A new Huffmanela species, H. mexicana n. sp. (Nematoda: Trichosomoididae), from the marine fish Sphoeroides annulatus in Mexico. Journal of Parasitology86, 1229-1231. 
Moravec, F., Justine, JL (2010). Some trichinelloid nematodes from marine fishes off New Caledonia, including description of Pseudocapillaria novaecaledoniensis sp. nov. (Capillariidae). Acta

Parasit. 55, 71-80. https://doi.org/10.2478/s11686-010-0005-7

Moravec F, Koudela B, Ogawa K, and Nagasawa K (1998). Two new Huffmanela species, H. japonica n. sp. and H. shikokuensis n. sp (Nematoda: Trichosomoididae), from marine fishes in Japan. Journal of Parasitology 84, 589-593.

Moravec F, Conboy GA, and Speare DJ (2005). A new trichosomoidid from the skin of Sebastes spp. (Pisces) from British Colombia, Canadian Journal of Parasitology91, 411-414.

Ramos P, Carvalho R, Rosa F, Alexandre-Pires G, Seixas F, Esteves A, and Huffman D (2019). Huffmanela lusitana sp. n. (Nematoda: Trichosomoididae) infecting pouting, Trisopterus luscus (Teleostei: Gadidae) off the Atlantic coast of Portugal. International journal of Parasitology: Parasites and Wildlife9, 266-273.

Ruiz CF and Bullard SA (2013). Huffmanela markgracei sp. n. (Nematoda: Trichosomoididae) from buccal cavity of Atlantic sharpnose shark, Rhizoprionodon terraenovae (Carcharhiniformes: carcharhinidae), in the northwestern Gulf of México off Texas. Folia Parasitologia60, 353-358.

Ruiz CF, Ray CL, Cook M, Grace MA, and Bullard SA (2013). A new species of Trichosomoididae (Nematoda) from skin of red snapper, Lutjanus campechanus [Perciformes: Lutjanidae], on the TexasLouisiana shelf, northern Gulf of Mexico. Journal of Parasitology99, 318-326.

Rowlerson A, Radaelli G, Mascarello F, \& Veggetti A (1997). Regeneration of skeletal muscle in two teleost fish: Sparus aurata and Brachydanio reri.Cell Tissue Research289, 311-322.

Saera-Vila A, Louie KW, Sha C, Kelly RM, Kish PE, Kahana A (2018). Extraocular muscle regeneration in zebrafish requires late signals from Insulin-like growth factors. PLOS ONE13 (2). e0192214.

Žd'árská Z, Huffman DG, Moravec F, Nebesářová J (2001). Egg shell ultrastructure of the fish nematode Huffmanela huffmani (Trichosomoididae). Folia Parasitologia48, 231-234.

\section{Figures}



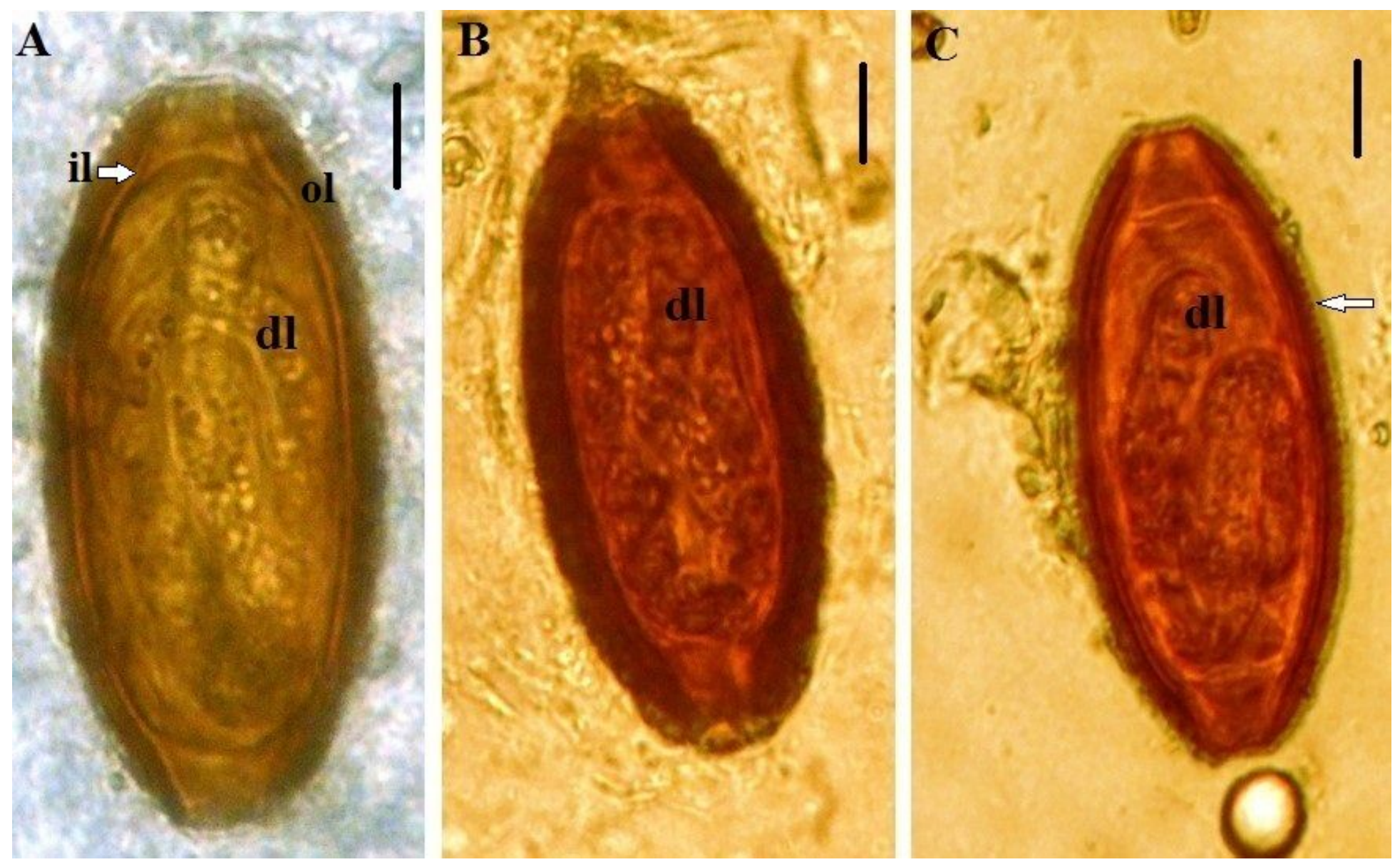

Figure 1

Developmental stages of Huffmanela spp. eggs from Orange spotted grouper; (A) stage 1: amber-shelled egg with bilayer eggshell observable with outer layer (ol) dark colored and innermost typically translucent with developing larva (dl), scale bar: $10 \mu \mathrm{m}$. (B; C) stage 2: fully developed brown-shelled egg with developing larva $(\mathrm{dl})$; note protuberance in outer layer (arrow); scale bar: $10 \mu \mathrm{m}$. 

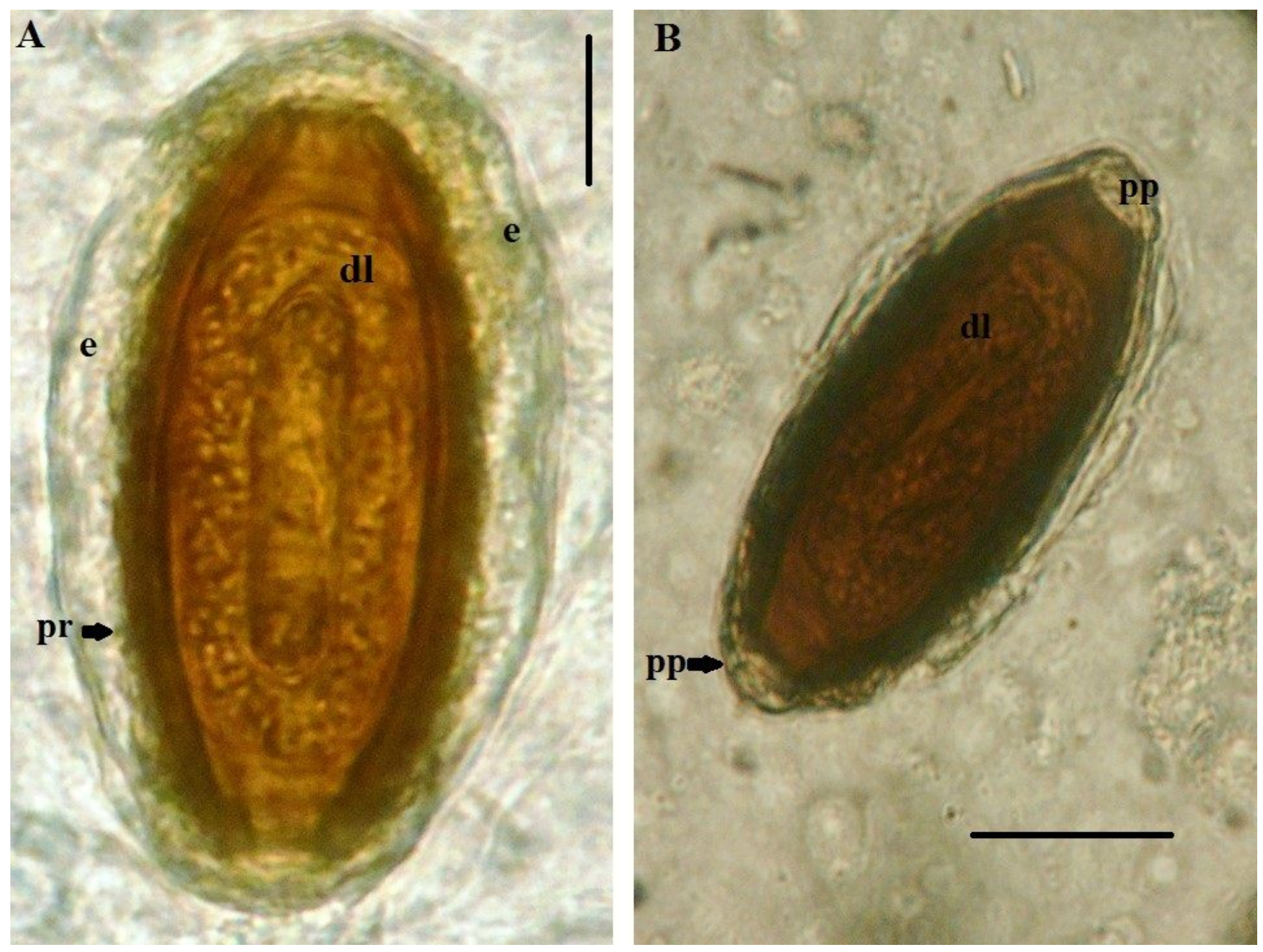

Figure 2

Developmental stages of Huffmanela spp. eggs from Orange spotted grouper (A) stage 2: fully developed brown-shelled egg with developing larva (dl); note protuberance $(\mathrm{pr})$ in outer layer, the eggs surrounded by smooth envelop (e); scale bar: $15 \mu \mathrm{m}$. (B) stage 2: fully developed brown-shelled egg with developing larva (dl); note protruding polar plug (pp); scale bar: $20 \mu \mathrm{m}$. 

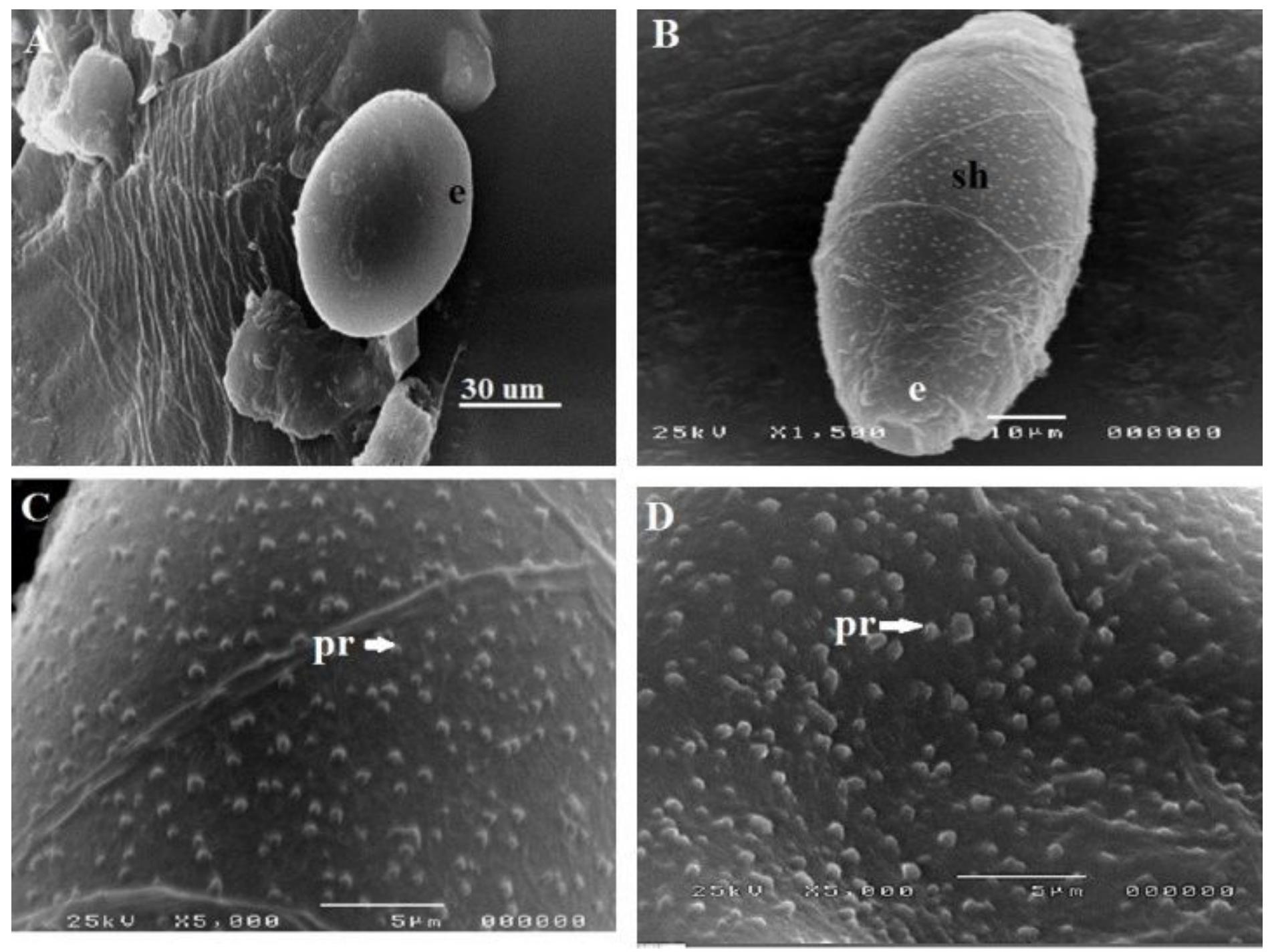

Figure 3

Developmental stages of Huffmanela spp. eggs from Orange spotted grouper; scanning electron micrographs. (A): Eggs of Huffmanela spp. note smooth envelop (e). (B): Eggs showing its shell (sh) had protuberance (pr) and remnant of envelop (e). (C): Higher magnification of eggs showing protuberance (pr). (D): Higher magnification of H. spp.eggs showing the eggshell surface with protuberance (pr) on it which appear as irregular protrusion. 


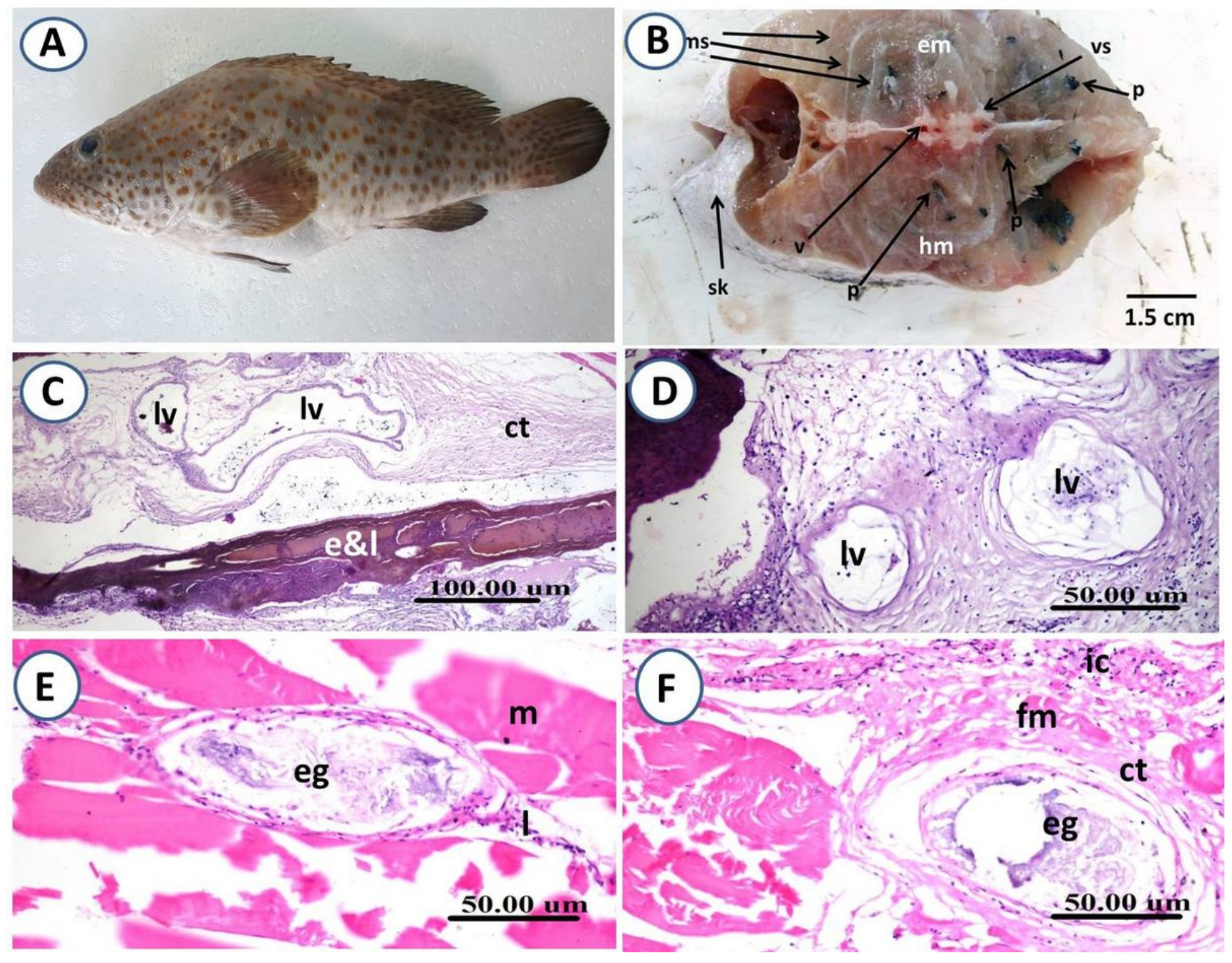

Figure 4

(A): Examined Epinephelus coioides in fish markets; (B): Cross section in the muscle of infected Epinephelus coioides showing blackish parasitic materials ( $p$ ) embedded in the epaxial and hepaxial muscles (em \& hm), around vertebrae (v), vertebral spines (vs) and near the myosepta (ms). The underlying muscular tissue under the skin (sk) is slightly infested. C-F: Histopathological sections of the infected muscular tissue of Epinephelus coioides showing (C): Eggs and larvae (e\&l) in the muscle with dilated lymph vessels (Iv) and delicate layer of fibrous connective tissue proliferation (ct); (D): Dilated lymph vessels (IV) and mononuclear inflammatory cells aggregation (ic); (E): Egg containing lavae of the Huffmanela spp. and proliferated (I) fibrous connective tissue capsule around the egg together with degenerated muscle fibers $(\mathrm{m})$ of the host tissue; $(\mathrm{F})$ : The egg (eg) surrounded with fibrous connective tissue proliferation (ct), fragmented necrotic muscle fibers ( $\mathrm{fm}$ ) and many of mononuclear cells infiltration (ic). (H\&E). 


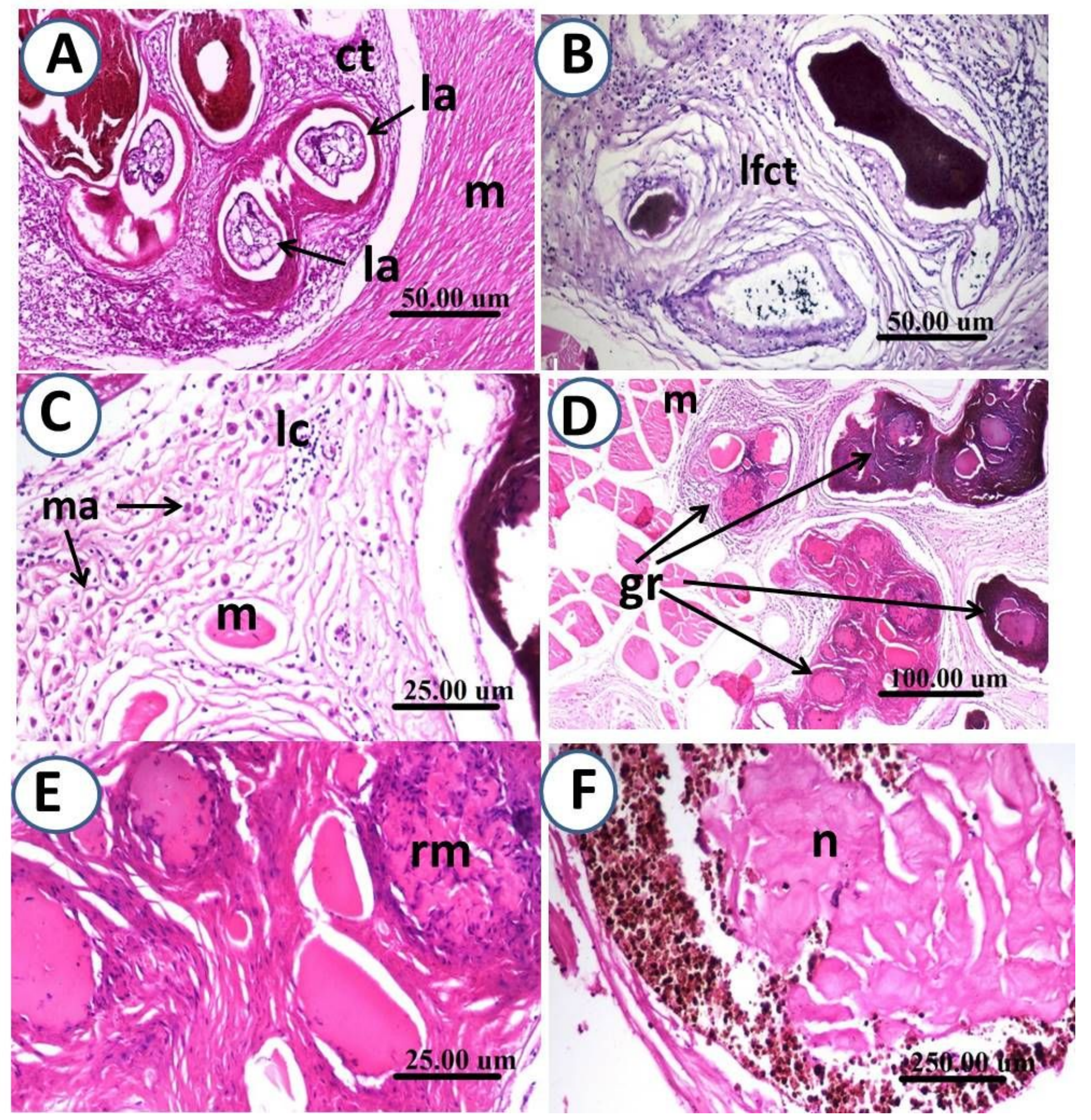

Figure 5

Histopathological sections of the infected muscle of Epinephelus coioides with Huffmanela spp. showing (A): Multiple eggs and larvae (la) forming chronic focal granulomatous lesion separating the muscular tissue [m]. the parasite elements surrounded with fibrous connective tissue capsule (ct); (B): Edematous and lamellated fibrous connective tissue proliferation (Ifct) surrounding the eggs; (C): Fragments of the necrotic muscular tissue $(\mathrm{m})$ of the host with macrophages $(\mathrm{ma})$ and other mononuclear inflammatory 
cells (ic); (D): Multiple intermuscular granulomas (gr) between the muscular tissue; (E): High power view of $D$ showing regenerated muscular tissue $(\mathrm{rm})$ with characteristic multiple and centrally located nuclei; (F): necrotic muscular tissue (n) surrounded with multiple melanophores. (H\&E). 